\title{
Cloning, expression and identification of an isoform of human stromal cell derived factor-1 $\alpha$
}

\author{
YIN-KU LIANG ${ }^{1,2}$, WEI PING ${ }^{1}$ and LIU-JIAO BIAN ${ }^{1}$ \\ ${ }^{1}$ College of Life Science, Northwest University, Xi'an, Shaanxi 710069; ${ }^{2}$ College of Biological Science and Engineering, \\ Shaanxi University of Technology, Hanzhong, Shaanxi 723000, P.R. China
}

Received June 29, 2014; Accepted February 26, 2015

DOI: $10.3892 /$ etm.2015.2355

\begin{abstract}
Human stromal cell derived factor-1 $\alpha$ (hSDF-1 $\alpha$ ), a chemotactic factor of stem cells, regulates inflammation, promotes the mobilization of stem cells and induces angiogenesis following ischemia. Six SDF-1 isoforms, SDF-1 $\alpha$,

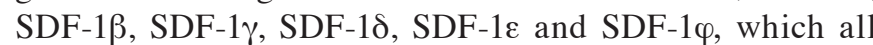
contain a signal peptide at the $\mathrm{N}$-terminus, have been reported. In the present study a special isoform of hSDF-1 $\alpha$ is described that does not contain the $\mathrm{N}$-terminal signal peptide sequence. The $h S D F-1 \alpha$ gene was cloned with the recombinant plasmid pCMV-SPORT6-hSDF1 as the template, and the prokaryotic expression vector $\mathrm{pET} 15 \mathrm{~b}-\mathrm{hSDF}-1 \alpha$ was constructed. This $\mathrm{hSDF}-1 \alpha$ was successfully expressed as an inclusion body in Escherichia coli BL21(DE3). The recombinant hSDF-1 $\alpha$ was refolded in vitro and separated by cation exchange chromatography. Following these two steps the purity of the hSDF-1 $\alpha$ was able to reach $>85 \%$. The recombinant hSDF-1 $\alpha$ was then purified by size-exclusion chromatography. SDS-PAGE analysis demonstrated that the purity of the hSDF-1 $\alpha$ was $>95 \%$, which meets almost all the requirements of a protein experiment. Chemotactic activity of the recombinant hSDF-1 $\alpha$ was analyzed by Transwell migration assay and it was found that the recombinant hSDF-1 $\alpha$ was able to stimulate THP-1 cell migration. These data suggest that the procedure of producing recombinant hSDF-1 $\alpha$ proteins with chemotactic activity was feasible and the N-terminal signal peptide of hSDF-1 $\alpha$ has little effect on the chemotactic activity of hSDF-1 $\alpha$.
\end{abstract}

\section{Introduction}

Ischemic cerebrovascular disease is a disease with a high incidence worldwide. Progress has been made in the treatment of ischemic cerebrovascular disease, and the application and curative effect of stem cells has become an area of

Correspondence to: Professor Liu-Jiao Bian, College of Life Science, Northwest University, 229 Taibai Road, Xi'an, Shaanxi 710069, P.R. China

E-mail: bianliujiao@sohu.com

Key words: human stromal cell derived factor- $1 \alpha$, cloning, purification, chemotactic activity increasing interest. Stromal cell derived factor 1 (SDF-1) is currently the strongest known chemotactic factor associated with stem cell mobilization. It can activate a series of signal transduction pathways through binding to its specific receptor CXC chemokine receptor 4 (CXCR4), and thus it plays a role in the regulation of inflammation, mobilization of stem cells and induction of angiogenesis following ischemia of tissues. Voermans et al (1) demonstrated that human SDF-1 $(\mathrm{hSDF}-1 \alpha)$ induced the aggregation of intracellular actin in $\mathrm{CD} 4^{+}$precursor cells, stimulated the tyrosine phosphorylation of focal adhesion proteins and changed cytoskeletal structures, and activated the migration of hematopoietic stem cells, by rhodamine staining and fluorescence-activated cell sorting. The combined effects of SDF-1 and vascular endothelial growth factor can markedly improve the survival time of endothelial cells. SDF-1 has been found to increase CD34 ${ }^{+}$ cell proliferation, inhibit apoptosis and promote the differentiation of CD34+ cells $(2,3)$, which indicates that SDF-1 plays an important role in the proliferation of hematopoietic stem cells and the process of homing and mobilization; therefore, studies on SDF-1 have attracted growing attention. SDF-1 was first found in cytokines secreted by the mouse bone marrow stromal cell line pA6 in 1994 (4). Since four conserved cysteine residues in the $\mathrm{C}$-terminal and two cysteines in the N-terminal of its amino acid sequence are separated by another amino acid, SDF-1 is classified into the CXC subfamily of chemokines, and is also known as CXCL12 (5). The $h S D F-1$ gene is located in chromosome 10q11.1 (6) and encodes different proteins due to its different splicing modes. The Gen Bank accession numbers for these different cDNAs and their associate proteins are SDF- $1 \alpha$, SDF-1 $\beta$, SDF- $1 \gamma$, SDF-1 $\delta$, SDF- $1 \varepsilon$ and SDF- $1 \varphi$. hSDF- $1 \alpha$ is an 89 -amino-acid protein while SDF-1 $\beta$, SDF- $1 \gamma$, SDF- $1 \delta$, SDF-1 $1 \varepsilon$ and SDF- $\varphi$ encode 93, 119, 120, 90 and 100-amino-acid proteins, in all of which the first 89 amino acids are identical to those of SDF- $1 \alpha(7,8)$. The full-length cDNA of $h S D F-1 \alpha$, which encodes 89 amino acids including the N-terminal signal peptide, is $\sim 270 \mathrm{bp}$. A signal peptide cleavage site exists between the twentieth and twenty-first amino acids of the N-terminal of hSDF-1 $\alpha$ (9). Crump et al (10) studied the NMR structure of SDF-1 in different solution conditions. The results showed that chemokine tertiary structure consists of a flexible N-terminus connected by an extended 'N-loop' and a single turn of a $3_{10}$-helix to a three-stranded $\beta$-sheet and a 
C-terminal $\alpha$-helix. The functional domain of the C-terminal is important to maintain SDF-1 conformation and the $\beta$-helix to regulate the activity of the SDF-1 in its interaction with glycosaminoglycans. The structure of the N-terminal is also important in its interactions with CXCR4; however the effect of the signal peptide on the activity of hSDF-1 $\alpha$ is unknown.

In the present study, the process and technology of cloning and expressing the hSDF-1 $\alpha$ protein without the N-terminal signal peptide was reported, and the chemotactic activity of the recombinant hSDF-1 $\alpha$ was identified. This study may help to understand the technology of the recombinant and purified $\mathrm{hSDF}-1 \alpha$, the diverse physiological functions of hSDF- $1 \alpha$, the activity of hSDF- $1 \alpha$ and the effects of $\mathrm{N}$-terminal signal peptide on the activity of hSDF-1 $\alpha$.

\section{Materials and methods}

HSDF-1 $\alpha$ cloning and expression vector construction. Primers were designed according to the $h S D F-1 \alpha$ cDNA sequence provided by the National Center for Biotechnology Information (NM_199168). The gene, which had mature peptide sequences of $213 \mathrm{bp}$ without the signal peptide, was cloned from the total DNA of the pCMV-SPORT6-SDF1 $\alpha$ plasmid (GeneCopoeia, Guangzhou, China) using polymerase chain reaction (PCR) amplification with sense primer 5'-GAT GCCATGGACGGGAAGCCCGTCAGC-3' and antisense primer 5'-CGCGGATCCTTACTTGTTTAAAGCTTTCTC CAGGT-3' (NcoI and BamHI restriction sites are underlined) (11). Primers were synthesized by the Beijing Dingguo Changsheng Biotechnology Co. Ltd. (Beijing, China). The PCR amplification conditions were as follows: $98^{\circ} \mathrm{C}$ for $5 \mathrm{~min}, 94^{\circ} \mathrm{C}$ for $30 \mathrm{sec}, 60^{\circ} \mathrm{C}$ for $30 \mathrm{sec}, 72^{\circ} \mathrm{C}$ for $30 \mathrm{sec}$ with a total of 30 cycles, and $72^{\circ} \mathrm{C}$ for $10 \mathrm{~min}$ for extension. PCR products were identified by $1.5 \%$ agarose gel electrophoresis, retrieved and purified with a gel extraction kit (Omega Bio-Tek, Inc., Norcross, GA, USA). The retrieved target fragments and vector pET-15b (Beijing Dingguo Changsheng Biotechnology Co. Ltd.) were double digested with NcoI and Bam HI restriction enzymes (Takara Bio Inc., Otsu, Japan) at $37^{\circ} \mathrm{C}$ for $6 \mathrm{~h}$, respectively. Digested fragments and plasmids were retrieved with a gel extraction kit (Takara Bio Inc.) and incubated with T4 ligase (Takara Bio Inc.) at a constant temperature of $16^{\circ} \mathrm{C}$ overnight. The ligation products were then transformed into competent cells of Escherichia coli (E.coli) DH5a (Beijing Dingguo Changsheng Biotechnology). The transformed DH5 $\alpha$ cells were cultured on Luria-Bertani (LB) solid medium containing $100 \mu \mathrm{g} / \mathrm{ml}$ ampicillin sodium salt (Sigma-Aldrich, St. Louis, MO, USA) overnight to screen the positive clones that were sent to Shanghai Biological Engineering Co. Ltd. (Shanghai, China) for sequencing. The recombinant plasmid was verified as correct by sequencing and named as pET-15b-hSDF-1 $\alpha$.

Inducible expression and analysis of recombinant protein $h S D F-1 \alpha$. The recombinant hSDF-1 $\alpha$ was expressed in the E. coli cell strain BL21(DE3) (Beijing Dingguo Changsheng Biotechnology). Bacterial cells transformed with the pET-15b-hSDF-1 $\alpha$ plasmid were grown in LB fluid medium supplied with $100 \mu \mathrm{g} / \mathrm{ml}$ ampicillin sodium salt at $37^{\circ} \mathrm{C}$ with shaking at $220 \mathrm{rpm}$ for $12 \mathrm{~h}$ (DDHZ-300; TaiCang
Experimental Equipment Factory, Suzhou, China). The following day, $1 \mathrm{ml}$ culture broth was inoculated in $100 \mathrm{ml}$ fresh LB fluid medium supplied with $100 \mu \mathrm{g} / \mathrm{ml}$ ampicillin sodium salt and grown at $37^{\circ} \mathrm{C}$ with shaking at $220 \mathrm{rpm}$ for $3 \mathrm{~h}$. Isopropyl $\beta$-D-1-thiogalactopyranoside (IPTG) was added at a final concentration of $1 \mathrm{mmol} / 1$ to induce gene expression for $\sim 8 \mathrm{~h}$ at $30^{\circ} \mathrm{C}$ with shaking at $220 \mathrm{rpm}$ until the optical density at $600 \mathrm{~nm}$ was 0.7 . Bacterial cells were subsequently collected by centrifugation at $4,444 \mathrm{x}$ g for $20 \mathrm{~min}$ at $4^{\circ} \mathrm{C}$ and frozen at $-20^{\circ} \mathrm{C}$. The expression of target proteins was analyzed by Tris-Tricine-SDS-PAGE electrophoresis (12).

Refolding of recombinant $h S D F-1 \alpha$ protein. The bacterial cell precipitate was mixed with ultrasound lysis buffer $(5 \mathrm{mmol} / \mathrm{l}$ EDTA disodium salt and $10 \mathrm{mmol} / \mathrm{l}$ Tris- $\mathrm{HCl}, \mathrm{pH}$ 8.0) at a ratio of $1: 10(\mathrm{w} / \mathrm{v})$. The precipitate containing recombinant hSDF-1 $\alpha$ was collected following ultrasonication centrifugation at $8,888 \mathrm{x} g$ for $10 \mathrm{~min}$ and dissolved by denaturing buffer $(6 \mathrm{~mol} / \mathrm{l}$ guanidine hydrochloride, $10 \mathrm{mmol} / 1 \beta$-mercaptoethanol, $5 \mathrm{mmol} / \mathrm{l}$ EDTA disodium salt and $10 \mathrm{mmol} / \mathrm{l}$ Tris-HCl, $\mathrm{pH}$ 8.0) at a ratio of 1:5 (w/v). The supernatant containing denatured recombinant hSDF-1 $\alpha$ was then collected by centrifugation at $8,888 \mathrm{x}$ g for $30 \mathrm{~min}$ and refolded by dropwise dilution at $4^{\circ} \mathrm{C}$ with stirring into refolded buffer $(10 \mathrm{mmol} / 1$ Tris $\mathrm{HCl}, \mathrm{pH} 8.0$, $5 \mathrm{mmol} / 1$ EDTA disodium salt, $1 \mathrm{mmol} / 1$ reduced glutathione and $0.2 \mathrm{mmol} / 1$ oxidized glutathione) to yield a final protein. Following stirring overnight at $4^{\circ} \mathrm{C}$ the refolded hSDF- $1 \alpha$ was isolated by centrifugation at $8,888 \times \mathrm{g}$ for $30 \mathrm{~min}$ and the supernatant containing the refolded recombinant hSDF- $1 \alpha$ was collected.

Separation and purification of recombinant refolded protein $h S D F-1 \alpha$. Cation exchange was necessary as the next step in purification (13). Elution buffer A $(0.3 \mathrm{~mol} / 1 \mathrm{NaCl}, 10 \mathrm{mmol} / \mathrm{l}$ Tris $\mathrm{HCl}, \mathrm{pH} 8.5$ ) was first used to equilibrate the chromatographic column. The supernatant containing the refolded recombinant hSDF-1 $\alpha$ was loaded onto a $5 \mathrm{ml}$ sulfopropyl (SP) Sepharose fast flow (FF) column (GE Healthcare Bio-Sciences, Pittsburgh, PA, USA) at $2 \mathrm{ml} / \mathrm{min}$ and then refolded recombinant hSDF-1 $\alpha$ was eluted from the SP Sepharose FF column in elution buffer B $(1 \mathrm{~mol} / 1 \mathrm{NaCl}$ and $10 \mathrm{mmol} / \mathrm{l}$ Tris $\mathrm{HCl}, \mathrm{pH}$ 8.5). The hSDF-1 $\alpha$ was detected by Tris-Tricine-SDS-PAGE electrophoresis.

Purification of recombinant refolded protein $h S D F-1 \alpha$ by size-exclusion chromatography. Size-exclusion chromatography was carried out on a Sephadex G-75 (GE Healthcare Bio-Sciences) column (1.5/60) with a flow rate of $1 \mathrm{ml} / \mathrm{min}$, while monitoring the absorbance at $280 \mathrm{~nm}$. The elution buffer was $10 \mathrm{mmol} / 1$ phosphate buffer ( $\mathrm{pH}$ 7.0) which was used to equilibrate the Sephadex G-75 column and elute hSDF-1 $\alpha$ protein. The hSDF-1 $\alpha$ was detected by Tris-Tricine-SDS-PAGE electrophoresis.

Determination of recombinant $h S D F-1 \alpha$ activity. A Transwell migration assay with a pore diameter of $8 \mu \mathrm{m}$ was used to detect the chemotactic migration of THP-1 monocytes to recombinant hSDF-1 $\alpha(14,15)$. THP-1 cells cultured for 3-5 generations were further cultured using serum-free medium RPMI-1640 (Hyclone, Logan, UT, USA) containing 


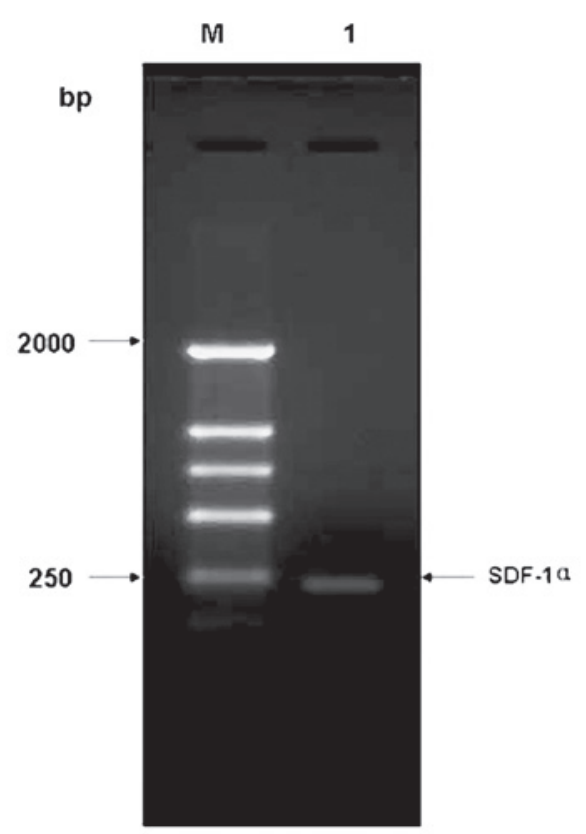

Figure 1. Agarose gel electrophoresis analysis of $h S D F-1 \alpha$ gene cloned from pCMV-SPORT6-hSDF1 by PCR. Lane M, DL2000 (DNA marker); Lane 1 PCR analysis of hSDF-1 $\alpha$ cDNA prepared from pCMV-SPORT6-SDF1 $\alpha$. hSDF, human stromal cell-derived factor; PCR, polymerase chain reaction.

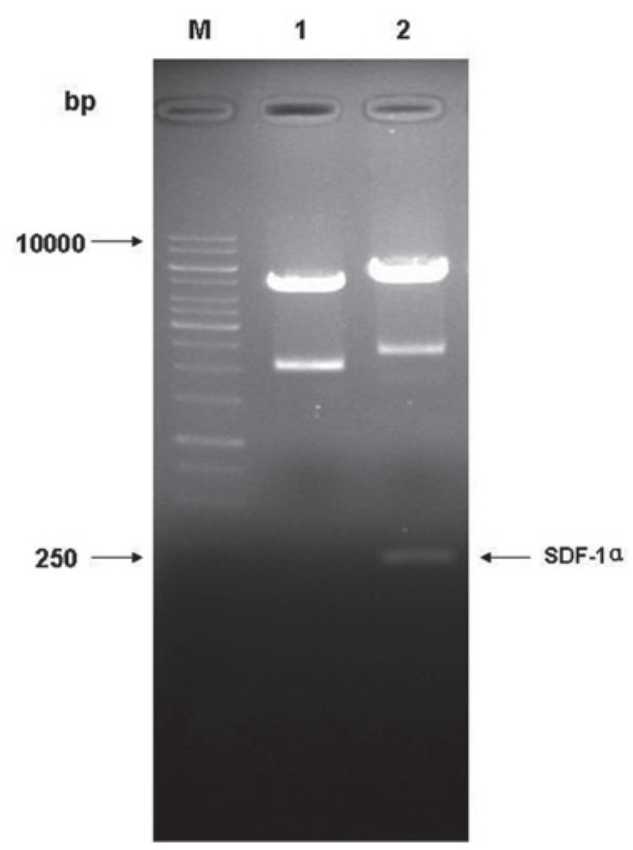

Figure 2. Identification of recombinant plasmid pET-15b-SDF1 $\alpha$ digested by restriction enzymes $\mathrm{NcoI}$ and BamHI. Lane M, middle marker; lane 1, pET-15b doubly digested with NcoI and BamHI; lane 2, pET-15b-SDF1 $\alpha$ doubly digested with $\mathrm{NcoI}$ and $\mathrm{BamHI}$. SDF, stromal cell-derived factor.

$0.2 \%$ bovine serum albumin (BSA; Sijiqing; Zhejiang Tianhang Biotechnology Co. Ltd., Beijing, China) for $12 \mathrm{~h}$. The cells were harvested and resuspended in RPMI-1640 containing $0.5 \%$ fetal bovine serum (FBS) at a concentration of $3 \times 10^{5}$ cells $/ \mathrm{ml}$. hSDF- $1 \alpha$ was prepared with concentrations of $0,10,100$ and $500 \mathrm{ng} / \mathrm{ml}$ in $10 \mathrm{mmol} / 1$ phosphate buffer (pH 7.0). A 600- $\mu 1$ amount of hSDF-1 $\alpha$ at each of the aforementioned concentrations was taken and added to 24-well plates (Beyotime Institute of Biotechnology, Jiangsu, China) in triplicate. A chamber insert was placed into the 24-well plate and $200 \mu 1$ cell suspension with a concentration of $3 \times 10^{5}$ cells $/ \mathrm{ml}$ was added to each chamber. The cells were then incubated in a $\mathrm{CO}_{2}$ incubator for $\sim 10 \mathrm{~h}$ and the cell numbers in each well were counted and calculated under a microscope (magnification, x200; TE2000-U; Nikon Corporation, Tokyo, Japan).

Determination of protein concentration. Standard protein assay procedures using the Rio-Rad Protein Assay kit (Bio-Rad Laboratories, Inc., Hercules, CA, USA) and BSA protein standards were used to determine the hSDF-1 $\alpha$ protein concentration.

\section{Results}

Construction and identification of pET-15b-hSDF-1 $\alpha$. The six known SDF-1 isoforms, SDF-1 $\alpha$, SDF-1 $\beta$, SDF- $1 \gamma$, SDF-1 $\delta$, SDF-1 $\varepsilon$ and SDF-1 $\varphi$ share the same first three exons but contain different fourth exons and have the same signal peptide at their 5'-end; therefore, the SDF-1 gene was amplified without the $\mathrm{N}$-terminal signal peptide sequences. Sense and antisense primers were designed to clone the $h S D F-1 \alpha$ gene. The amplified target fragment identified by $1.5 \%$ agarose gel electrophoresis was $\sim 213$ bp (Fig. 1), indicating that the $h S D F-1 \alpha$ gene was successfully amplified, and was consistent with the theory. The amplified target fragment was cloned into the pET-15b vector. The double-enzyme digestion results demonstrated a band of 213 bp in lane 2, suggesting that the target gene was successfully inserted into vector pET-15b (Fig. 2). The positive recombinants identified by double-enzyme digestion were further sequenced, and the alignment results revealed that the sequence of the constructed recombinant vector and reading frame were correct, indicating that the recombinant prokaryotic expression vector named pET-15b-hSDF-1 $\alpha$ was successfully constructed.

Expression of recombinant protein $h S D F-1 \alpha$. The recombinant vector pET-15b-hSDF-1 $\alpha$ was transformed into E. coli BL21(DE3) to express the $h S D F-1 \alpha$ gene. The hSDF-1 $\alpha$ protein was analyzed with Tris-Tricine-SDS-PAGE following induction. A band was clearly observed with a molecular weight corresponding to that estimated from the deduced amino acid sequence, and the recombinant hSDF-1 $\alpha$ appeared in the precipitate of cell lysates (Fig. 3), suggesting that the recombinant hSDF-1 $\alpha$ was successfully expressed in the form of an inclusion body in E. coli BL21(DE3). Due to the inactivity of the aggregated form of hSDF-1 $\alpha$, it was necessary for the hSDF-1 $\alpha$ to be dissolved and refolded in vitro, to provide biologically active hSDF- $1 \alpha$. Optimal refolding efficiency of hSDF- $1 \alpha$ required optimal conditions of refolding; thus the inactive hSDF- $1 \alpha$ was refolded under optimized refolding conditions. Bradford method analysis following refolding revealed a refolding rate of $27 \%$. Cation exchange chromatography required preparation of the refolded hSDF-1 $\alpha$ sample in a low-salt-containing buffer prior to loading on the cation exchange column to remove 


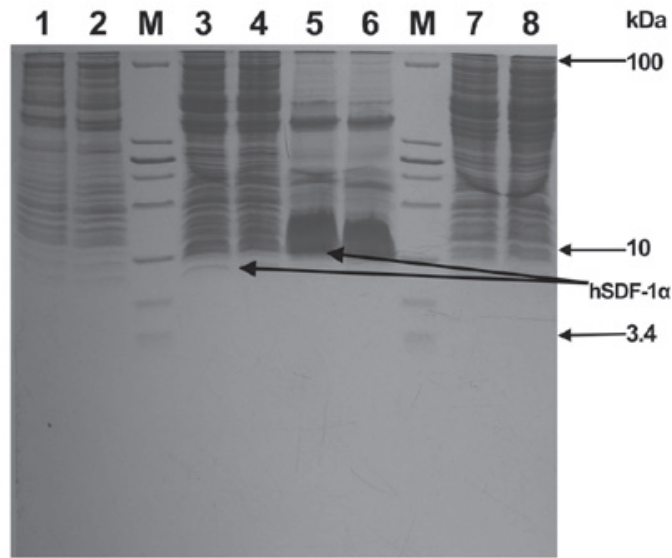

Figure 3. Expression of recombinant bacteria E.coli BL21(DE3)/pET15bSDF1 $\alpha$. Lane M, low protein molecular weight marker (from top to bottom the molecular weights are 100,30,25, 20,15, 10, 5 and $3.4 \mathrm{kDa}$ ); Lanes 1 and 2, bacteria were cultured at $37^{\circ} \mathrm{C}$ with shaking at $220 \mathrm{rpm}$ for $2.5 \mathrm{~h}$ and then cultured at $30^{\circ} \mathrm{C}$ with shaking at $220 \mathrm{rpm}$ for $6 \mathrm{~h} .1 \mathrm{ml} \mathrm{bac}-$ teria was boiled and analyzed by Tris-Tricine-SDS-PAGE electrophoresis; Lanes 3 and 4 , bacteria were cultured at $37^{\circ} \mathrm{C}$ with shaking at $220 \mathrm{rpm}$ for $2.5 \mathrm{~h}$ and then cultured at $30^{\circ} \mathrm{C}$ with shaking at $220 \mathrm{rpm}$ for $6 \mathrm{~h}$ following the addition of isopropyl $\beta$-D-1-thiogalactopyranoside. $1 \mathrm{ml}$ bacteria was boiled and analyzed by Tris-Tricine-SDS-PAGE electrophoresis; Lanes 5 and 6 , the precipitation of bacterial lysates was analyzed by Tris-Tricine-SDS-PAGE electrophoresis; Lanes 7 and 8, The supernatant of the bacterial lysates was analyzed by Tris-Tricine-SDS-PAGE electrophoresis. hSDF, human stromal cell-derived factor.

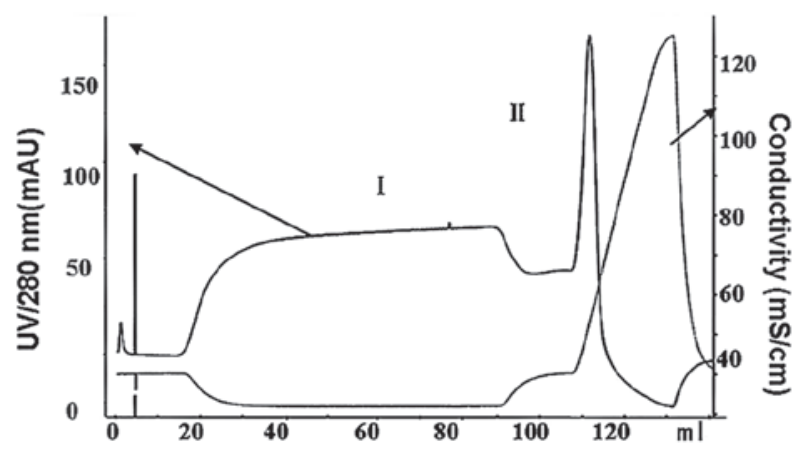

Figure 4. Chromatogram of the refolding solution from a SP Sepharose FF column. Recombinant hSDF-1 $\alpha$ samples were purified with an ion exchange SP Sepharose FF prepacked column following refolding. SP, sulfopropyl; FF, fast flow; hSDF, human stromal cell-derived factor.

any salt or contaminating materials which would inhibit binding of hSDF-1 $\alpha$ to the column. The refolding process only dilutes the concentration of salt and does not remove other impurities.

Separation and purification of the recombinant refolded protein $h S D F-1 \alpha$. A low concentration of refolded hSDF- $1 \alpha$ protein with a high level of impurity necessitated strong cation exchange and size-exclusion chromatography. Strong cation exchange chromatography under refolding conditions was employed to remove the majority of the truncated product, accomplished by thorough washing with cation exchange buffer (elution buffer A). hSDF-1 $\alpha$ was eluted from the strong cation exchange column in cation exchange buffer (elution

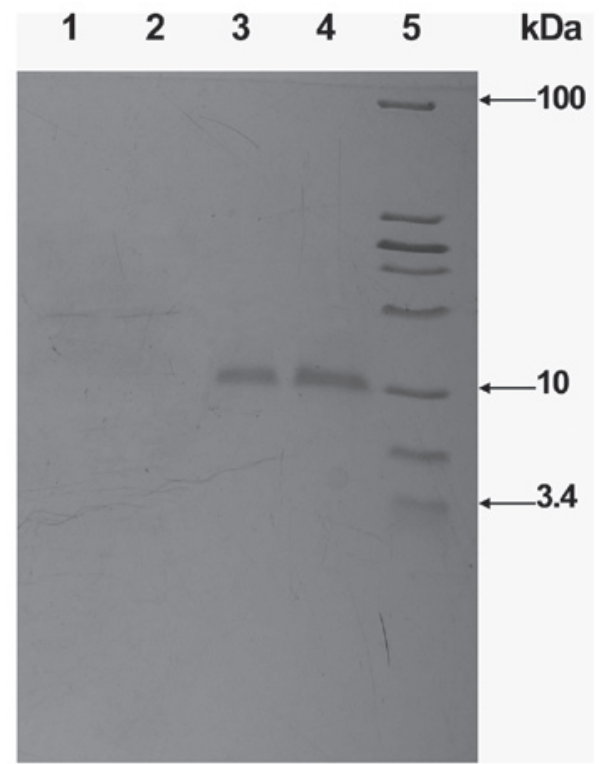

Figure 5. SDS-PAGE analysis of the protein fractions collected from the SP Sepharose FF column. Lanes 1 and 2, proteins which did not bind to the column (Peak I in Fig. 4); Lanes 3 and 4, protein eluted by elution liquid B (Peak II in Fig. 4); Lane 5, molecular weight marker (from top to bottom the molecular weights are 100,30, 25, 20, 15, 10, 5 and $3.4 \mathrm{kDa}$, respectively).

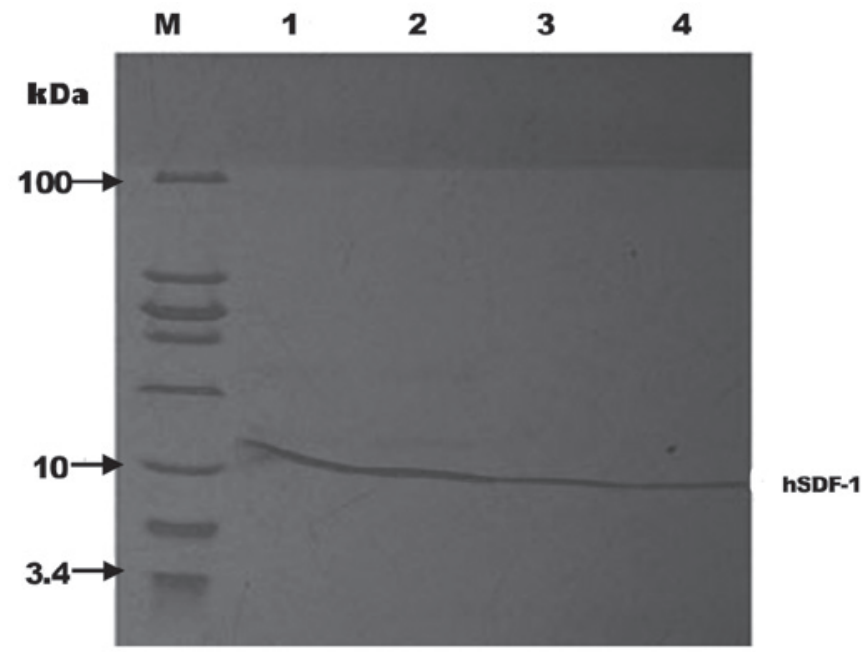

Figure 6. SDS-PAGE analysis of the protein fractions collected from strong cation exchange and size-exclusion chromatography. Lanes 1 and 2, proteins collected from strong cation exchange chromatography; Lanes 3 and 4 , proteins collected from size-exclusion chromatography; Lane M, molecular weight marker (from top to bottom the molecular weights are 100, 30, 25, 20, $15,10,5$ and $3.4 \mathrm{kDa}$, respectively). hSDF, human stromal cell-derived factor.

buffer B). During the elution process of $0-100 \%$ B, peaks I and II were observed in the chromatogram of the refolding solution. Tris-Tricine-SDS-PAGE analysis following strong cation exchange showed that hSDF-1 $\alpha$ existed in peak II with an impurity at $\sim 15 \%$ abundance (Figs. 4 and 5). Strong cation exchange was followed by size-exclusion chromatography under refolding conditions. This step removed higher and lower molecular mass impurities. Tris-Tricine-SDS-PAGE analysis following size-exclusion chromatography showed that 
A

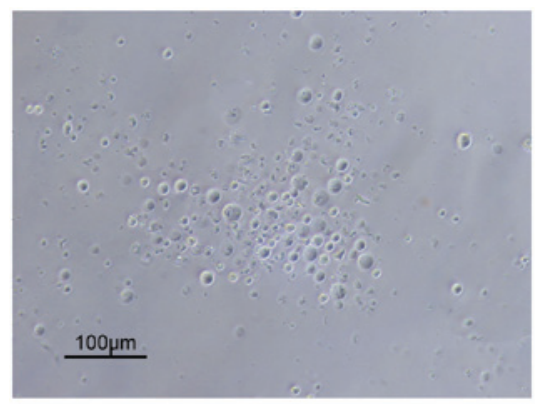

C

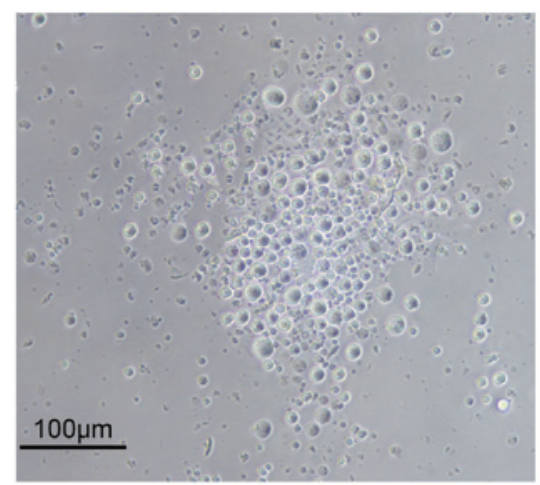

B

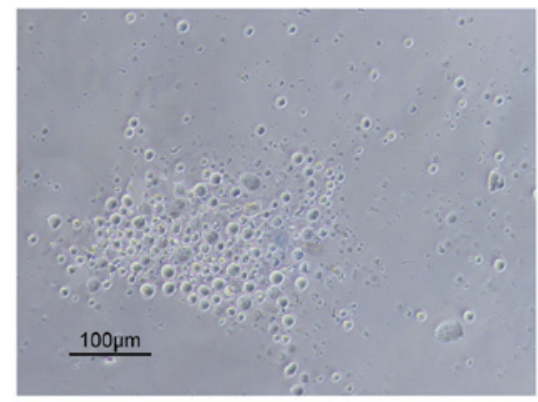

D

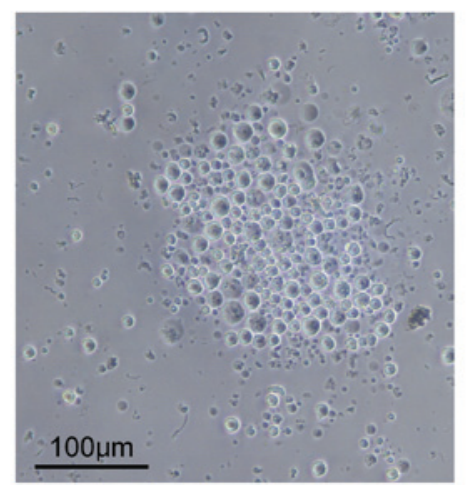

Figure 7. THP-1 cell migration stimulated by purified recombinant hSDF-1 $\alpha$. The different concentrations of the recombinant hSDF- $1 \alpha$ are (A) $0 \mathrm{ng} / \mathrm{ml}$, (B) $10 \mathrm{ng} / \mathrm{ml}$, (C) $100 \mathrm{ng} / \mathrm{ml}$ and (D) $500 \mathrm{ng} / \mathrm{ml}$. hSDF, human stromal cell-derived factor.

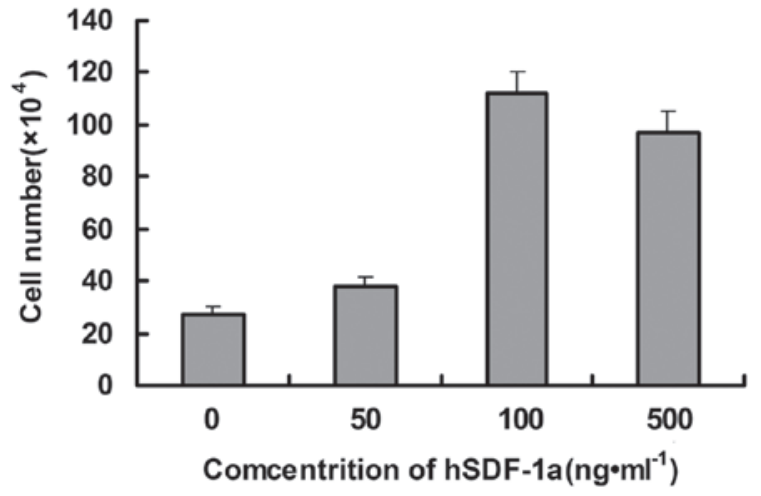

Figure 8 . Chemotaxis assay. THP-1 cell migration stimulated by purified recombinant hSDF-1 $\alpha$. Mean values and standard deviations are calculated from data of triplicate wells. hSDF, human stromal cell-derived factor.

there were few impurities, indicating that the target protein could be obtained by purification using strong cation exchange and size-exclusion chromatography (Fig. 6).

Determination of recombinant $h S D F-1 \alpha$ activity. The effects of recombinant hSDF-1 $\alpha$ on the chemotactic activity of THP-1 cells were investigated by Transwell cell migration assay, with RPMI-1640 containing $0.5 \%$ FBS as a control. The number of cells that migrated to the lower chamber with recombinant hSDF-1 $\alpha$ protein concentrations of 10,100 and $500 \mathrm{ng} / \mathrm{ml}$ was significantly higher than that of the control group, indicating that a chemotactic effect of the purified recombinant mutant hSDF-1 $\alpha$ protein occurred in the THP-1 cells (Figs. 7 and 8), demonstrating that the cloned, expressed, refolded and purified recombinant mutant hSDF-1 $\alpha$ in the present study had high biological activity.

\section{Discussion}

SDF- $1 \alpha$ is a protein that plays an important role in the migration, proliferation, differentiation and adhesion of endothelial progenitor cells (EPCs) in vivo. CXCR4 is a specific receptor of SDF-1, and is a G protein-coupled receptor composed of 352 amino acids and containing a seven transmembrane helical structure. CXCR4 is widely expressed in bone marrow mononuclear cells and stem cells (16). The interaction between CXCR4 and SDF-1 not only regulates the release of stem cells from bone marrow into the peripheral circulation but also regulates the recruitment and residence of stem cells in ischemic tissues $(17,18)$, which plays an important role in the application of stem cell therapy for hypoxia, ischemic heart disease and brain injury $(19,20)$. Crystal structure and NMR studies have demonstrated that hSDF-1 $\alpha$ binds to CXCR4 in its monomeric form, and the eight amino acids of the $\mathrm{N}$-terminus form an important receptor binding region, whereas the C-terminus of SDF-1 is not involved in receptor binding (7). Yu et al (8) studied NEK293 cells transfected with SDF-18, which has an additional 50 amino acids on the C-terminals, and therefore is $>50 \%$ longer than hSDF- $1 \alpha$. The study showed the presence of secreted protein at $\sim 14 \mathrm{kDa}$, the correct molecular size to be the intact protein, suggesting that the C-terminals of SDF-1 $\delta$ were not cleaved. This demonstrated that SDF-1 $\delta$ was also able to stimulate CXCR4-mediated clathrin-mediated endocytosis cell migration in a similar manner to hSDF-1 $\alpha$. This research showed that the activity of hSDF-1 $\alpha$ was associated with its structure.

In the present study, hSDF-1 $\alpha$ without a signal peptide sequence was created and an efficient protocol for cloning, expression and purification of the recombinant protein was developed. The $h S D F-1 \alpha$ cDNA sequence which did not 
contain the $\mathrm{N}$-terminal signal peptide sequence was successfully constructed in a pET-15b vector, and hSDF- $1 \alpha$ was efficiently expressed in E. coli BL21(DE3) cells in the form of an inclusion body. Prior to being separated and purified by strong cation exchange chromatography, the recombinant $\mathrm{hSDF}-1 \alpha$ was refolded with oxidized glutathione and reduced glutathione. This process not only diluted the concentration of salt but also removed certain impurities and improved the subsequent separation efficiency. The purity of the recombinant hSDF-1 $\alpha$ reached $>85 \%$ following cation exchange chromatography, which meets the requirements of general protein experiments. Size-exclusion chromatography was then used to separate out the hSDF-1 $\alpha$. Tris-Tricine-SDS-PAGE analysis showed that the purity of the recombinant $\mathrm{hSDF}-1 \alpha$ reached $>95 \%$, which meets the requirements of all protein experiments. To determine if the recombinant hSDF-1 $\alpha$ was functional, a chemotaxis assay evaluating the ability of $\mathrm{hSDF}-1 \alpha$ to stimulate the migration of cells expressing the CXCR4 receptor, was performed using THP-1 cells. The recombinant hSDF-1 $\alpha$ stimulated THP-1 cell migration, showing that the recombinant hSDF-1 $\alpha$ had bioactivity, and indicating that the N-terminal signal peptide of hSDF-1 $\alpha$ had little effect on the activity of hSDF-1 $\alpha$. Further studies are required to determine if there are quantitative differences in chemotaxis activities; however the present study laid a good foundation for further study of the $h S D F-1 \alpha$ gene, the function of the recombinant hSDF-1 $\alpha$ protein and the mechanism of interaction of $\mathrm{hSDF}-1 \alpha$ with its specific receptor CXCR4.

\section{Acknowledgements}

The authors would like to thank the National Basic Research Program of China (no. 21075097).

\section{References}

1. Voermans C, Anthony EC, Mul E, van der Schoot E and Hordijk P: SDF-1-induced actin polymerization and migration in human hematopoietic progenitor cells. Exp Hematol 29: $1456-1464,2001$

2. Shi HW, Zhang P, Wang CM and Han H: Prokaryotic expression and purification of fusion protein GST-SDF-1 $\alpha$. Ke Xue Ji Shu Yu Gong Cheng 7: 3365-3367, 2007 (In Chinese).

3. Yao F, Zhou JM, Wang Z, Wei DH, Jiang ZS, Liu LS and Tong ZY: Cloning and sequence analysis of SDF-1 $\alpha$ gene in rats. Zhongguo Shi Yan Dong Wu Xue Bao 16: 14-18, 2008 (In Chinese).

4. Nagasawa T, Kikutani H and Kishimoto T: Molecular cloning and structure of a pre-B-cell growth-stimulating factor. Proc Natl Acad Sci USA 91: 2305-2309, 1994.
5. Psenák O: Stromal cell-derived factor-1 (SDF-1). Its structure and function. Cas Lek Cesk 140: 355-363, 2001 (In Czech).

6. Shirozu M, Nakano T, Inazawa J, Tashiro K, et al: Structure and chromosomal localization of the human stromal cell derived factor-1 (SDF-1) gene. Genomics 28: 495-500, 1995.

7. Gleichmann M, Gillen C, Czardybon M, Bosse F, et al: Cloning and characterization of SDF- $1 \gamma$, a novel SDF-1 chemokine transcript with developmentally regulated expression in the nervous system. Eur J Neurosci 12: 1857-1866, 2000.

8. Yu L, Cecil J, Peng SB, Schrementi J, Kovacevic S, Paul D, Su EW and Wang J: Identification and expression of novel isoforms of human stromal cell-derived factor 1. Gene 374: 174-179, 2006.

9. Feng Y: Cloning of SDF-1 $\alpha$ gene and effect on migration of THP-1 (PhD thesis). Nanhua University, 2006.

10. Crump MP, Gong JH, Loetscher P, Rajarathnam K, Amara A, Arenzana-Seisdedos F, Virelizier JL, et al: Solution structure and basis for functional activity of stromal cell-derived factor-1; dissociation of CXCR4 activation from binding and inhibition of HIV-1. EMBO J 16: 6996-7007, 1997.

11. Yu M, Liang Q, Lu HL, Mao WW, Wu MY, Wang Q and Han W: Expression and purification of human SDF-1 $\alpha$ in prokarotic cells and its regulative role in murine bone marrow hematopoiesis. Xian Dai Sheng Wu Yi Xue Jin Zhan 7: 836-839, 2007 (In Chinese).

12. Cao ZW: An effective method of Tricine-SDS-PAGE for separating the $1 \mathrm{kDa}$ peptide. Zhong Guo Sheng Wu Gong Cheng Za Zhi 38: 74-76, 2003 (In Chinese).

13. Miao L, Xu LH, Ji X and Bian LJ: Cloning, expression, purification and its biological activity study of the soluble tripolymer recombinant angiogenesis inhibitor kringle 5. Sheng Wu Gong Cheng Jin Zhan 31: 18-22, 2011 (In Chinese).

14. Kodali RB, Kim WJ, Galaria II, Miller C, Schecter AD, Lira SA and Taubman MB: CCL11 (Eotaxin) induces CCR3-dependent smooth muscle cell migration. Arterioscler Thromb Vasc Biol 24: 1211-1216, 2004.

15. Lv YC, Wang Z, Wei DH et al: The chemotactic activity of stromal cell derived factor $1 \alpha$-CXCR 4 to the migration of THP- 1 cell and enhanced effect of oxidized low density lipoprotein. Zhongguo Dong Mai Ying Hua Za Zhi 15: 15-18, 2007 (In Chinese).

16. Wu B, Chien EY, Mol CD, Fenalti G, Liu W, Katritch V, Abagyan R, Brooun A, Wells P, Bi FC, et al: Structures of the CXCR4 chemokine GPCR with small-molecule and cyclic peptide antagonists. Science 330: 1066-1071, 2010.

17. Penn MS: Importance of the SDF-1:CXCR4 axis in myocardial repair. Circ Res 104: 1133-1135, 2009.

18. Jujo K, Hamada H, Iwakura A, Thorne T, Sekiguchi H, Clarke T, Ito A, Misener S, Tanaka T, Klyachko E, et al: CXCR4 blockade augments bone marrow progenitor cell recruitment to the neovasculature and reduces mortality after myocardial infarction. Proc Natl Acad Sci USA 107: 11008-11013, 2010

19. Li YJ, Cai XX, Ma GS, Chen ZH, Tang CC and Feng Y: The short-term prognostic value of stromal cell-derived factor-1 $\alpha$ in patients with acute myocardial infarction. Nanjing Gongye Daxue Xxuebao: Ziran Kexue Ban 31: 1781-1784, 2011 (In Chinese).

20. Stumm RK, Rummel J, Junker V, Culmsee C, Pfeiffer M, Krieglstein J, Höllt V and Schulz S: A dual role for the SDF-1/CXCR4 chemokine receptor system in adult brain: isoform-selective regulation of SDF-1 expression modulates CXCR4-dependent neuronal plasticity and cerebral leukocyte recruitment after focal ischemia. J Neurosci 22: 5865-5878, 2002 . 